\title{
"WILD LEAGUE" IN WATER POLO: AN EXPLORATION OF RECREATIONAL SPORTS EVENT VISIT MOTIVATION
}

\author{
Joško Sindik \\ Institute for Anthropological Research, Zagreb, Croatia
}

\begin{abstract}
Scope of this study was to identify motivational factors related to specific recreational sport event: "Wild league" in water polo, which takes place in Dubrovnik, have very long tradition. First goal of the study is to determine the relationship between motivational factors related to this event, as well as with socio-demographic variables. Second goal is to determine the differences in motivational factors, according to several independent variables, mainly related to the previous experiences with sports and touristic destination. The cross-sectional study is conducted. The sample of 125 participants was examined, using the Questionnaire on sports event. All participants were Croatian citizens, excluding those who are born, and currently live in Dubrovnik. Major sports tourism motives of the potential tourists in this sporting event, were obtained. In general, the importance of the benefits of sports and tourist destination prevailed, as compared with their limitations, which appeared as an important factor only in participants who didn't visited Dubrovnik yet. At the participants, pull factors, i.e. advanced sports and travel motives slightly dominated over push motives, but statistically significant only in females, who expressed more sophisticated pulling tourist motives, such as the acquisition of knowledge about the destination. Correlations indicate that previous interest in sport, particularly in water polo and Wild League, are moderate positively associated with pushing motives. Moreover, previous recreationally engaging in sports, as well as destination-related origin, appeared as the important factors for having more emphasized pull motives for visiting this sport event. Level of the education did not appear as important factor in differentiating main type of motives in target population. Results provide initial information about the possibility of profiling potential tourists who could be motivated to visit the destination by this particular sports event.
\end{abstract}

Keywords: DUBROVNIK, PUSH AND PULL FACTORS, SPORT TOURISM

\section{INTRODUCTION}

This research has a fundamental purpose of a framework to explore the motivation for sports tourism in the context of recreational water polo competition Wild League in Dubrovnik. The insights from this study can provide the guidance on the possibility of improving conditions for sports and / or cultural tourism in terms of the local attractive recreational-sports event.

\section{Sports tourism}

Sports tourism includes travel from the primary residence for the purpose of participating in sports activities (recreational or competitive), travel by participating in sports competitions elite level, as well as visits to sporting attractions such as water parks or "houses of the fame" (Gibson, Attle, \& Yiannakis, 1997; Gibson, 2004). The basic resources of a particular tourist destination are natural and cultural resources, tourist facilities, communications infrastructure, accommodation and the restaurants. The combination of local tourism resources and the services that are offered, determines the type of tourism, which belongs to a particular place: for example, coastal (marine), mountain tourism, sport, religious tourism, gastronomic, conference, or business tourism (HM Government, 2014). 


\section{Motives in sports tourism: push and pull factors}

Tourism and sport are the key elements of contemporary culture, having an important impact on the society as a whole (Ottevanger, 2007; Whyte, Hood, \& White, 2012). Within the sports tourism, there is an essential difference between active and passive participating sports audience. The last (several dozen) years there has been a significant increase in sports tourism related to sporting events, and for many tourists, attending or participating in sporting events, has become the main reason for travel (Delpy, 1997). Most of the motives of sports tourism in the literature tends to categorize the reasons for tourist travel motives as "escaping from" (e.g. the noise, working everyday routine, routine in general, etc.) and / or "running on" (e.g. places where you can confidently relax or entertain) certain destination (Pizam, \& Mansfeld, 2000; Mohamed, \& Othman, 2012).

A "pushing" (push) factors represent mostly socio-psychological motivation, based on the need "running away from" everyday current human environment. The desire to escape on certain tourist destination (due to its attractiveness, or some other reason), can be called "pulling" (pull) factors (Ottevanger, 2007). Dann (1977, from Kim, \& Chalip, 2004) provides a basic model with seven different categories of tourist motivations. these are: tourist trips which are the response to what is currently missing to someone (pushing factors); the attractiveness of a particular destination (pulling factors); wish to fulfill own fantasy; motivation with a clear purpose, such as visiting friends and relatives or learning; different types of motivation; already experienced motivational experience; motivation which is self-defined (with the meaning that it is better to define tourists within certain situations, not only observing their behavior). Crompton deepens Dann's theory of pushing and pulling factors, and believes that there are nine motives for tourist travels, seven of which are socio-psychological or pushing motives, while the other two are cultural or pulling motives (Crompton, 1979, from Kim, \& Chalip, 2004). Pushing motives are escape, self-exploring, relaxation, prestige, regression and social interactions. Pulling motives are the novelty and education. Two main types of pushing and pulling motives could be identified: personal and interpersonal (Mannel, \& Iso-Ahola, 1987, from Pizam,
\& Mansfeld, 2000). They point out that the purpose of both types of motives is the fact that people want to leave behind personal or interpersonal problems and find personal or interpersonal awards. Personal awards are self-determination, sense of competence, challenge, learning, exploring and relaxing. Interpersonal awards are the result of social interactions (Pizam, \& Mansfeld, 2000).

\section{Other categorizations of sports tourism motivation}

Hall's (1992) model distinguishes between two types of active participation in sports tourism: active participants consider their participation as a medium of self-expression, while the competitors have strong competitive motives in this active participation. On the other hand, passive consumers of sport do not participate in sports activities, but they are following these major sports events, by visiting distinguished sports websites or monitoring of sports news. Gammon and Robinson's (1997) model differentiates two forms of sports tourism: the term "sports tourism“ is used if sport is the main reason for travel, while the term "tourism sport" is used when the participation in sports activities is secondary activity among many others. Standeven and De Knop (1999) made the distinction between different sports tourism purposes. One principle is based on the purpose of rest (someone travel to rest and for some of them it is not a purpose of their holidays), while the other principle is a presence or the absence of need to be active and passive sports tourists. Passive sports tourists are those who want to visit sporting events or sports museums. Active sports tourists can engage in sports activities with the rest, where the sport is the main purpose of travel, or in vacation with sports activities, where the sport is a subsidiary activity. In addition to the authors who differ participating actively and passive audience, there are also several other theories. Weed and Bull (2004) distinguish five categories of sports tourism: sports training, sports events, elite sports events, sports tourism with the active participation and tourism with occasional involvement in sports activities. Reeves (2000, from Hinch, \& Higham, 2004) identified six different types of sports tourism visitors, divided as: random, sporadic, occasional, regular, committed and driven. 


\section{Previous findings}

Among numerous studies in this area, Green \& Chalip (1998) investigated the female soccer players in the United States, which took part in the annual tournament in Florida. Their research revealed that playing football not away from home or the place (Florida) is not the motive, which attracts players, but the fact that they could be together with colleagues engaged in the same sport, from distant places the United States. Kim \& Chalip (2004) investigated 600 Americans attending the FIFA World Cup in South Korea and Japan in 2002, obtaining the findings that the main reason for their visit to South Korea and/or Japan was their interest in the World Cup. Financial constraints have influenced negatively on people going to similar events. It is interesting that the people themselves have the ability to create a quality of some sports center. The example of such new appeared „sports center" is a collection of football fans who watch matches in public places on a temporary set TV screens, e.g. during the World Cup in Germany in 2006 (Hinch, \& Higham, 2004). Gathering people creates a place that attracts people who were not interested in particular sport, but just like "being in a sports atmosphere". There are three qualities of the importance of sports tourism: attachment to the place, the identity of the place and dependence on a place (Hinch, \& Higham, 2004). In a study of a motivation for visiting Wimbledon tournament, it was shown that the motives of the parties are the main reason why people want to visit this great sporting event, while the second motive is the attractiveness of the host-destination (Ottevanger, 2007). It was surprising that the festivities around the event for the spectators were more important than the competition itself. The visit to this great sporting event (unlike other forms of the tourism), had not be seen as a "time for a break" (Ottevanger, 2007).

\section{Wild League as a sports event}

Owning a strong position of the City of Dubrovnik as a destination of culture tourism means inventing new forms of presentation and promotion of this touristic center (Rudan, 2012), while in the same time striving to keep the Dubrovnik tradition and culture (Vrtiprah 2006). The local traditional sporting (in fact recreational sports) events, which are observed by tourists or in which they actively participate, may be developed into an attractive touristic product (Šiljeg, Perinić Lewis, \& Sindik, 2014). The Wild league ("Divlja liga"), as a cultural and sports event, offers a wide variety of impressive, formal cultural products. It is simultaneously a lively and layered tradition, as well as the spirit of the local Dubrovnik atmosphere (Šiljeg et al., 2014). The Wild league is a popular amateur water polo competition, which is taking place in Dubrovnik's beaches. Although it is based solely on the enthusiasm and the volunteer activities of all of the participators and organizers, its rules and regulations are precisely defined and well respected (Šiljeg et al., 2014). This tournament has an exceptionally local character. The first precondition for play in in this tournament is being a local inhabitant (Divlja liga 2015). The fact that Wild league tournament is held between end-July and mid-August, means that this local recreational sport activity might be much better integrated into the touristic offer, representing the cultural and economic potential of the City and the County (Šiljeg et al., 2014).

Hence, as the component of the sports (recreational) and cultural tourism product, the Wild league ought to be better emphasized in Dubrovnik's touristic offer. The challenges of affirming the Wild league as Dubrovnik's distinct brand are being explored in this study, by the insight in differences and correlations between sports touristic motives, different sociodemographic variables, as well as the issue-related variables (interest in sports, Dubrovnik's heritage, etc.).

Therefore, the overall objective of the research was to determine the factors related to sports tourism in the context of recreational water polo competition Wild League in Dubrovnik, in Croatian citizens, who may actually be potential tourists. The first goal of the study was to determine the correlation between the very different motives of sports tourism, and then the correlation between these motives with participants' age, their education level and the duration of follow-up of this sporting event. The second goal was to determine the differences in the motives of sports tourism in relation to the gender and marital status of participants. 


\section{METHOD}

\section{Participants}

The purposeful sample of 125 participants was examined. The wide inclusion criterion was Croatian citizenship, excluding those participants who are born, and currently live in Dubrovnik. By their age group $(\mathrm{N})$, the distribution of participants was as following: 21-30 (17), 31-40 (35), 41-50 (42), 51-60 (24), age $>60$ (5). By gender, there were 44 male and 81 female participants. By the frequency of previous being in Dubrovnik and its environment $(\mathrm{N})$, the distribution of participants was as following: never (5), less or equal twice (26), 3-5 (46), more than 6 times (48). By the reason why someone most often came in Dubrovnik and its environment $(\mathrm{N})$ the distribution of participants was as following: never in Dubrovnik (5), business (22), private - touristic (77) and private - other reasons (21). According to educational level $(\mathrm{N})$, participants are distributed as follows: high school (6), college (bacc.) (16), graduate (mag.) (66), master of science (19) and Ph.D. (18). According to their engaging in sports $(\mathrm{N})$, participants are distributed as follows: not interested in sports (4), no time for playing sports (10), playing sports recreation in the past (26), playing sports actively in the past (23), playing sports recreation now (58), playing sports actively now (4). According to Dubrovnik's heritage, 110 participants have not Dubrovnik's heritage, 6 have closer relatives, while 9 were born in Dubrovnik or its environment. According to the interest in sports (Likert scale with the range from 1 - absolutely not interested to 5 - absolutely interested), the median is 4 (interested in sports). According to the interest in water polo (Likert scale in range from 1 - absolutely not interested to 5 absolutely interested), the median is 3 (indifferent about water polo). For the question "Have you ever heard about Wild League?" (with Likert scale with the range from 1 - never heard about to 5 - very familiar with this event), the median is 3 .

\section{Measures}

The study used adjusted questionnaire about the sports tourism (Questionnaire on sports event), used by Ottevanger (2007, based on Pizam, \& Mansfeld 2000; Robinson, \& Gammon, 2004).
The first set of the items relates to the majority of the demographic variables and previous sports experience, while the items No. 1-8 are related to the pushing factors (categories: escape from everyday life, relaxation, self-exploration, fun and socializing). Items No. 9-16 refer to the pulling factors (categories: news, self-development and destination). Finally, items No. 17-20 relate to restrictions (category: the risks and threats). The estimates for each item are expressed on a Likert scale of five degrees, varying in range from strongly disagree (1) to strongly agree (5). In this study, the dimensions of the questionnaire showed satisfying reliability type internal consistency. Cronbach's alpha for pushing factors was 0.885 , for pulling factors 0.736 and for limitations 0.638). The questionnaire was distributed to the participants, translated in Croatian language. The data were collected from October to November 2015, by online survey (Google Surveys tool), while the participants are informed about scientific purpose of the research and guaranteed anonymity.

\section{Statistical analysis}

The correlations were calculated by Spearman's rank-correlation coefficients, while the differences between two independent samples of subjects are tested with t-tests for independent samples or Mann Whitney U-test. Kruskal Wallis tests are used for testing the differences among more than two independent sample of subjects. All statistical significances are commented on the significance level at $\mathrm{p}<0.05$ and $\mathrm{p}$ $<0.01$. Statistical analysis are performed using statistical package IBM SPSS 23.0.

\section{RESULTS}

Table 1 shows the differences in the motives of sports tourism, by participants' gender and Dubrovnik heritage. No statistically significant gender differences in the motives of sports tourism were found. In terms of Dubrovnik heritage (closer relatives or born in Dubrovnik vs. without Dubrovnik's heritage), only significant difference is found in pushing motives. Participants with Dubrovnik's heritage showed more pronounced pushing motives, than those who do not have this heritage. 
Table 1. Differences in the motives of sports tourism, by gender and Dubrovnik heritage

\begin{tabular}{llccc}
\hline Motives & Gender & $\mathbf{M}$ & SD & t-test (df=99) \\
\hline pushing & male & 25.53 & 7.75 & 1.88 \\
\multirow{2}{*}{ pulling } & female & 22.22 & 8.46 & \\
\multirow{2}{*}{ limitations } & male & 22.00 & 4.64 & 0.04 \\
& female & 21.96 & 5.30 & \\
& male & 7.94 & 2.75 & -1.34 \\
\hline \multirow{2}{*}{ Motives } & female & 8.78 & 3.04 & Mann Whitney \\
& Heritage & $\mathbf{M}$ & SD & U-test \\
\multirow{2}{*}{ pushing } & no & 22.21 & 8.11 & $\mathbf{- 4 . 8 1}$ \\
& yes & $\mathbf{3 1 . 0 8}$ & 5.65 & \\
\multirow{2}{*}{ limiting } & no & 21.88 & 5.06 & -0.51 \\
& yes & 22.67 & 5.37 & \\
& no & 8.58 & 2.87 & 0.64 \\
\hline
\end{tabular}

${ }^{*}$ difference is significant at $\mathrm{p}<0.01 ;{ }^{*}$ difference is significant at $\mathrm{p}<0.05$

The differences in motives of sports tourism, according to personal engagement in sports, were not statistically significant (Table 2).

Table 2. Differences in the motives of sports tourism, by personal engagement in sports

\begin{tabular}{|c|c|c|c|c|c|}
\hline Motives & Engaging in sports & Med & $\mathbf{M}$ & SD & Kruskal Wallis (p) \\
\hline \multirow{3}{*}{ pushing } & not (not interested or no time) & 23 & 20.09 & 8.07 & \multirow{3}{*}{0.38} \\
\hline & $\begin{array}{l}\text { yes, active or recreational in the } \\
\text { past }\end{array}$ & 22 & 23.10 & 8.78 & \\
\hline & yes, active or recreational now & 22 & 24.10 & 8.04 & \\
\hline \multirow{3}{*}{ pulling } & not (not interested or no time) & 22 & 20.91 & 3.81 & \multirow{3}{*}{0.27} \\
\hline & $\begin{array}{l}\text { yes, active or recreational in the } \\
\text { past }\end{array}$ & 22 & 21.63 & 4.59 & \\
\hline & yes, active or recreational now & 23 & 22.48 & 5.67 & \\
\hline \multirow{3}{*}{ limitations } & not (not interested or no time) & 11 & 8.45 & 3.91 & \multirow{3}{*}{0.64} \\
\hline & $\begin{array}{l}\text { yes, active or recreational in the } \\
\text { past }\end{array}$ & 9 & 8.23 & 2.72 & \\
\hline & yes, active or recreational now & 8 & 8.76 & 2.96 & \\
\hline
\end{tabular}

** difference is significant at $\mathrm{p}<0.01 ;^{*}$ difference is significant at $\mathrm{p}<0.05$

Differences in the motives of sports tourism by the most often reasons for being in Dubrovnik are statistically significant both for pushing motives and limitations (Table 3). Participants who are going in Dubrovnik because of private - other visits have the highest pushing motives, while the lowest medians are found for private - touristic visits. On the other hand, participants who have never been in Dubrovnik perceive the highest limitations, while the limitations are the least for these who are coming in Dubrovnik because of private - other reasons. 
Table 3. Differences in the motives of sports tourism by the most often reasons for being in Dubrovnik

\begin{tabular}{|c|c|c|c|c|c|}
\hline Motives & $\begin{array}{l}\text { The most often } \\
\text { reason for being in } \\
\text { Dubrovnik }\end{array}$ & Median & Mean & $\begin{array}{c}\text { Std. } \\
\text { Deviation }\end{array}$ & Kruskal Wallis (p) \\
\hline \multirow{4}{*}{ pushing } & never in Dubrovnik & 23 & 23.50 & 5.51 & \multirow{4}{*}{$0.02^{*}$} \\
\hline & business & 22 & 22.28 & 9.26 & \\
\hline & private - touristic & 22 & 21.97 & 8.06 & \\
\hline & private - other & 31 & 29.00 & 6.97 & \\
\hline \multirow{4}{*}{ pulling } & never in Dubrovnik & 22 & 20.75 & 4.03 & \multirow{4}{*}{0.93} \\
\hline & business & 22 & 22.33 & 6.10 & \\
\hline & private - touristic & 23 & 21.79 & 4.70 & \\
\hline & private - other & 23 & 22.53 & 5.77 & \\
\hline \multirow{4}{*}{ limitations } & never in Dubrovnik & 11 & 11.75 & 0.96 & \multirow{4}{*}{$0.04^{*}$} \\
\hline & business & 9 & 9.50 & 2.71 & \\
\hline & private - touristic & 8 & 8.13 & 2.85 & \\
\hline & private - other & 8 & 8.12 & 3.39 & \\
\hline
\end{tabular}

${ }^{* *}$ difference is significant at $\mathrm{p}<0.01{ }^{*}$ difference is significant at $\mathrm{p}<0.05$

In Table 4, the correlations between the motives of sports tourism, educational level, age group and other variables are presented, for all participants together and separately for males and females. For pushing motives, the correlations with other variables (except the intercorrelations between sport motives) have very similar sizes, directions and levels of significance for males, females and all participants together. Positive and moderately high correlations are found with variables: interest in sports in general, interest in water polo and previous knowledge of Wild league. For pulling motives, the correlations with other variables are in general with lower sizes (although positive directed) than for pushing motives. All these correlations with pulling motives were non-significant for males, while for all participants significant correlations are found with the interest in water polo and previous knowledge of Wild league. Only in females, significant correlations with pulling motives are found with the interest in water polo. Finally, the only low and negative correlation with the limitations is found between previous being in Dubrovnik (and its environment), for all participants and for females (not in males). Although pushing and pulling motives are moderately high and positively intercorrelated in all three samples of participants, pulling motives moderately and positively correlate with limitations only in males. 
Table 4. Correlations between the motives of sports tourism, educational level, age group and other variables

\begin{tabular}{|c|c|c|c|}
\hline All participants & pushing & pulling & limitations \\
\hline educational level & -.020 & -.102 & -.048 \\
\hline age group & .125 & .027 & -.028 \\
\hline $\begin{array}{l}\text { How many times in Dubrovnik (and } \\
\text { environment)? }\end{array}$ & .130 & -.058 & $-.293^{* *}$ \\
\hline How much interested in sports in general? & $.431^{\star *}$ & .175 & .156 \\
\hline How much interested in sports in water polo? & $.601^{* *}$ & $.318^{* *}$ & .064 \\
\hline Have you ever heard of Wild league before? & $.454^{* *}$ & $.201^{*}$ & -.088 \\
\hline pushing motives & 1 & $.575^{* *}$ & .166 \\
\hline pulling motives & & 1 & .186 \\
\hline limitations & & & 1 \\
\hline Males & pushing & pulling & limitations \\
\hline educational level & .031 & -.324 & -.096 \\
\hline age group & .145 & -.019 & -.125 \\
\hline $\begin{array}{l}\text { How many times in Dubrovnik (and } \\
\text { environment)? }\end{array}$ & -.052 & -.229 & -.265 \\
\hline How much interested in sports in general? & $.407^{*}$ & .337 & .324 \\
\hline How much interested in sports in water polo? & $.554^{* *}$ & .190 & .037 \\
\hline Have you ever heard of Wild league before? & $.516^{* *}$ & .203 & .019 \\
\hline pushing motives & 1 & $.582^{* *}$ & .248 \\
\hline pulling motives & & 1 & $.602^{* *}$ \\
\hline limitations & & & 1 \\
\hline Females & pushing & pulling & limitations \\
\hline educational level & -.059 & -.012 & -.016 \\
\hline age group & .117 & .047 & .017 \\
\hline $\begin{array}{l}\text { How many times in Dubrovnik (and } \\
\text { environment)? }\end{array}$ & .135 & -.004 & $-.271^{*}$ \\
\hline How much interested in sports in general? & $.398^{* *}$ & .139 & .183 \\
\hline How much interested in sports in water polo? & $.594^{* *}$ & $.381^{* *}$ & .130 \\
\hline Have you ever heard of Wild league before? & $.392^{* *}$ & .210 & -.079 \\
\hline pushing motives & 1 & $.585^{* *}$ & .176 \\
\hline pulling motives & & 1 & .039 \\
\hline limitations & & & 1 \\
\hline
\end{tabular}

\section{DISCUSSION}

At first, when considering average values of scores for pushing, pulling motives and perceived limitations in sport tourism, linked with the Wild League (for all participants in total, for different independent variables), it could be noticed that scores for pushing and pulling motives are around or slightly above theoretical average. On the other hand, perceived limitations are around of slightly below theoretical average. These findings might indicate two explanations.
First, that the Wild League is very specific sports (or/ and cultural) event, which is attractive for specific profiles of tourists only. Secondly, the reputation of Dubrovnik as touristic destination has a potential to prevail many limitations, perceived by tourists, especially those who had visited Dubrovnik before.

Differences in the motives of sports tourism were not obvious by gender or by participant's personal engagement in sports. Dubrovnik's heritage appeared as the factor linked with stronger pushing motives. Similarly, stronger pushing motives were more relat- 
ed with travelling to Dubrovnik because of private causes (non-touristic). Pushing motives were more strongly linked with interest in sports in general, as well as in the water polo and (more) previous knowledge about Wild league.

Based on these findings, it seems that the pushing motives of this specific type of sports (and cultural) tourism were more emphasized for the participants who have some relatives (or friends) in Dubrovnik, independently of gender and personal engagement in sports. They probably have more positive experiences about staying in Dubrovnik, not (only) linked with sports or cultural events. It could be considered that pushing factors of positive motivation for sports tourism might overcome the constraints in our participants, who are probably giving stronger attention to the benefits of this sports tourism destination, more than on the restrictions (Sindik, 2014). This specific setting on benefits can potentially indicate the attractiveness of this tourist destination for tourists (Ottevanger, 2007). Consequently, it is understandable that the participants who had never been in Dubrovnik perceived the highest limitations, while negative correlations are found between previous visiting Dubrovnik (and its environment), in all participants and in females. Positive intercorrelation between pushing and pulling motives in all participants, could be explained simply in terms of the attractiveness of some touristic destination, which can be simultaneously place for relaxing (running away from) and place which is particularly attractive destination (going to this place) (Kim, \& Chalip, 2004). Pulling motives are positively and significantly associated with the interest in water polo, but only in females. As tentative "advanced" psychological motives (attractiveness of the destination is more important than escape from everyday life), it seems like pulling motives are more linked with this specific interest in female participants. This finding could be surprising, but not when considering the fact that sport tourism (especially this sports recreational, which is more cultural than typical sport event). Namely, for active physical exercising, for example in the student population, male students are more motivated by intrinsic factors (need for power, competition and challenge), females are more often driven by extrinsic motives (body weight control and appearance) (Egli, Bland, Melton, \& Czech, 2011). Active participation is sport could be attractive for several types of motives: fun, enjoyment, improving skills, and learning, being with friends, success, winning and health (Gaston-Gayles, 2005; Mouratadis, Vansteenkiste, Lens, \& Sideridis, 2008; Waldron, \& Dieser, 2010). Probable reason why pulling motives positively correlate with limitations only in males could be more emphasized need for rest in males, than in females. The need to be relaxed through sports and physical activities could be stronger emphasized in men (Egli et al., 2011). In the previous research with similar measuring instrument in Croatia, the results revealed that women observers of particular sport event (windsurfing championship) have more pronounced pulling motives (innovation and education) (Sindik, 2014). Similarly, possible explanation could lead in direction that women are not just "funs" of the recreational water polo players. They might have more sophisticated interests than men have (sport, cultural, etc.). Overall, it seems like that about the Wild league event, the attractiveness of the destination is at least similarly important as the sport recreational event. On the contrary, in the case of the Wimbledon tennis tournament (Ottevanger, 2007) or the World Cup in South Korea and Japan in 2002 (Kim, \& Chalip, 2004), the sports event itself were the dominant reason for visiting certain destination. However, Wild League is probably more cultural tourism event than sport recreational. Richards (2002) suggests that an increase in cultural tourism stems from the growing supply of cultural attractions and a growing number of tourists. The growth of the cultural tourism market is accompanied by the segmentation of the market, but also by the increasing competition (Outspan Group Inc., 2009). Within this competition, new market opportunities could be seen through the development of creative tourism (Richards, 2002; Rudan, 2012).

The main shortcoming of the study is relatively small and insufficiently representative (purposeful) sample of participants. This is also the reason of limited possibility of greater generalizability of the results obtained. In spite of this relatively small number of participants, applying the original measuring instrument showed satisfactory reliability and discriminability. However, although the possibility of generalization of the findings in this study is small, the results may give some insight into the motivation of potential tourists motivated by Wild league as a sport-recreational and cultural event. As a fundamental advantage of the research can be highlighting the fact that this is probably the only study that quantitatively studied Wild league as the "discrete touristic 
potential" (Šiljeg et al. 2014). Therefore, the practical implication of this study could be mainly related toward using these indicators and belonging measuring instrument (however, as well as these preliminary results) in estimation the Wild league as the "discrete touristic potential". The opportunities within the sport tourism field, by maximizing the potentials of some destination by understanding all elements integral to sport tourism (Delpy, 1997), could be applied in this case, too. Namely, the Wild League within could be put into various touristic packages, linked with other sports and/ or cultural offer.

\section{CONCLUSION}

The results revealed that there were no statistically significant gender differences in the motives of sports tourism, as well as according to participant's personal engagement in sports, while only one significant difference is found by Dubrovnik's heritage. Participants with Dubrovnik's heritage showed higher pushing motives, than those without Dubrovnik's heritage. Highest pushing motives showed the par- ticipants who are going in Dubrovnik because of private reasons - other visits, while the participants who have never been in Dubrovnik perceive the highest limitations. Positive and moderately high correlations with pushing motives are found with interest in sports in general and in water polo, previous knowledge of Wild league. Only in females, significant correlations with pulling motives are found with the interest in water polo. Low and negative correlation with the limitations is found between previous being in Dubrovnik (and its environment), in all participants and in females. Pushing and pulling motives positively intercorrelated in all three samples of participants, while pulling motives positively correlate with limitations only in males. The most reasonable explanations of the results obtained are that the Wild League is very specific sports and cultural event, which is attractive only for specific profiles of tourists. On the other hand, Dubrovnik itself is very attractive destination, which prevails many perceived limitations. Therefore, there are many possibilities to put the Wild League within few interesting touristic packages, linked with other sports and/ or cultural offer.

\section{REFERENCES}

1. Delpy, L. (1997). An overview of sport tourism: Building towards a dimensional framework. Journal of Vacation Marketing, 4(1), 23-28.

2. Divlja liga [Wild League. In Croatian] (2013). Propozicije [Propositions. In Croatian] Retrieved 18.12.2015. from http://www.divljaliga. $\mathrm{com} /$ ?page $=$ propozicije.

3. Egli, T., Bland, H.W., Melton, B.F. \& Czech, D.R. (2011). Influence of age, sex and race on collegestudents' exercise motivation of physical activity. Journal of American College Health, 59(5), 399-406.

4. Gammon, S., \& Robinson, T. (1997). Sport and tourism: A conceptual framework. Journal of Sport Tourism, 4(3), 8-24.

5. Gaston-Gayles, J.L. (2005). The Factor Structure and Reliability of the Student Athletes' Motivation toward Sports and Academics

Questionnaire (SAMSAQ). Journal of College Student Development, 46, 317-327.

6. Gibson, H. (2004). Moving beyond the „what is and who" in sport tourism to understanding „why“. Journal of Sport Tourism, 9(3), 247-265.

7. Gibson, H., Attle, S., \& Yiannakis, A. (1997). Segmenting the sport tourist market: A lifespan perspective. Journal of vacation marketing, $4(3), 52-64$.

8. Green, B., \& Chalip, L. (1998). Sport tourism as a celebration of sub-culture. Annals of Tourism Research, 25(2), 275-291.

9. Hall, C. (1992). Hallmark tourist events: Impacts, management and planning. London, GB: Bellhaven Press.

10. Hinch, T., \& Higham, J. (2004). Sport Tourism Development. Clevedon: Channel View Publications. 
11. HM Government (2014). Review of the Balance of Competences between the United Kingdom and the European Union Culture, Tourism and Sport, London: UK Government.

12. Kim, N.S., \& Chalip, L. (2004). Why to travel to the FIFA World Cup? Effects of motives, background, interest, and constraints. Tourism Management, 25, 695-707.

13. Mohamed, N., \& Othman, N. (2012). Push and Pull Factor: Determining the Visitors' Satisfactions at Urban Recreational Area. Procedia - Social and Behavioral Sciences, 49, 175-182.

14. Mouratadis, M., Vansteenkiste, M., Lens, W., \& Sideridis, G. (2008). The motivating role of positive feedback in sport and physical education: Evidence for a motivational model. Journal of Sport and Exercise Psychology, 30, 240-268.

15. Ottevanger, H.J. (2007). Sport Tourism: Factors of influence on sport event visit motivation. Master thesis. Bournemouth, UK: Bournemouth University.

16. Outspan Group Inc. (2009). The Economic Impacts of Cultural and Sport Tourism in Canada 2007. Ottawa: Department of Canadian Heritage and Industry Canada.

17. Pizam, A., \& Mansfeld, Y. (2000). Consumer behaviour in travel and tourism. New York: Haworth Hospitality Press,.

18. Richards, G. (2002). Od kulturnog do kreativnog turizma: europske perspective [From the cultural and creative tourism: European perspectives. In Croatian]. Turizam, 50(3), 228-236.

19. Robinson, T., \& Gammon, S. (2004). A question of primary and secondary motives: revisiting and applying the sport tourism framework. Journal of Sport Tourism, 9(3), 221-233.
20. Rudan, E. (2012). Razvojne perspektive kreativnoga turizma Hrvatske [Development perspectives of creative Croatian tourism. In Croatian]. Ekonomska misao i praksa, 21(2), 713-730.

21. Sindik, J. (2014). Percepcije Svjetskog prvenstva u jedrenju na dasci 2013. u Vignju sa stanovišta promatrača i natjecatelja [Perceptions of the World Championships in windsurfing in 2013 in Viganj from the viewpoint of the observer and competitors. In Croatian]. Naše more, 61(3-4), 81-88.

22. Standeven, J. \& De Knop, P. (1999). Sport Tourism. Leeds: Human Kinetics.

23. Šiljeg, K., Perinić Lewis, A., \& Sindik, J. (2014). Lokalna sportska tradicija kao dio dubrovačkoga kulturnog identiteta [Local sporting tradition as part of the cultural identity of Dubrovnik. In Croatian]. Zbornik Sveučilišta u Dubrovniku, 1(1), 93-208.

24. Vrtiprah, V. (2006). Kulturni resursi kao činitelj turističke ponude u 21. stoljeću [Cultural resources as a factor of tourism in the 21st century. In Croatian]. Ekonomska misao $i$ praksa, 15(2), 279-296.

25. Waldron, J.J., \& Dieser, R.B. (2010). Perspectives of fitness and health in college men and women. Journal of College Student Development, 51, 65-78.

26. Weed, M., \& Bull, C. (2004). Sport Tourism: Participants, Policy and Providers. Burlington: Elsevier Publishing.

27. Whyte, B., Hood, T., \& White, B.P. (eds). (2012). Cultural and Heritage Tourism: A Handbook for Community Champions. Ottawa, Canada: Federal Provincial Territorial Ministers of Culture and Heritage. 


\title{
„WILDE LIGA“ IM WASSERBALLSPORT: UNTERSUCHUNG DER MOTIVATION FÜR DEN BESUCH VON REKREATIVEN SPORTVERANSTALTUNGEN
}

\begin{abstract}
Zusammenfassung:
Der Zweck dieser Untesuchung ist die Identifizierung von Motivationsfaktoren, die mit einer bestimmten rekreativen Sportveranstaltung verbunden sind: die „Wilde Liga“ im Wasserballsport, die in Dubrovnik organisiert wird und eine sehr lange Tradition hat. Das erste Ziel dieser Studie ist es, das Verhältnis unter den, mit dieser Veranstaltung verbundenen Motivationsfaktoren und der Beziehung zu soziodemographischen Variablen festzulegen. Ein weiteres Ziel ist es, die Unterschiede zwischen den Motivationsfaktoren auf Grund einiger unabhängiger Variablen festzulegen, die hauptsächlich auf frühere Erfahrungen in Bezug auf Sport- und Tourismusbestimmungsorte hinweisen. Es wurde eine Transversalstudie durchgeführt. Ein Muster von 125 Teilnehmern wurde mit Hilfe eines Fragebogens über die Sportveranstaltung befragt. Alle Teilnehmer sind kroatische Staatsbürger, eine bestimmte Anzahl der Teilnehmer an dieser Studie wurde in Dubrovnik geboren und lebt im Moment in dieser Stadt. Gewonnen wurden auf diese Weise die wichtigsten Sport- und Tourismusmotive potentieller Touristen, die für diese Sportveranstaltung interessiert sind. Im allgemeinen Sinne hat die Bedeutung der Vorteile des Sport- und Tourismusbestimmungsorts Übergewicht im Vergleich zu Begrenzungen, die einen bedeutenderen Faktor bei Teilnehmern darstellten, die Dubrovnik nie besucht haben. Bei den Teilnehmern weisen die Anziehungsfaktoren bzw. höhere Sport- und Tourismusmotive eine geringe Dominanz im Vergleich zu Abstoßfaktoren auf, sind aber im statistischen Sinne nur bei Frauen bedeutend, die sophistiziertere Anziehungsfaktoren anführten wie z.B. Wissenserwerb über den Standort. Korrelationen weisen darauf hin, dass ein früheres Interesse für Sport, in besonderem Maße für Wasserball und die Wilde Liga, gemäßigt positiv mit den Abstoßmotiven verbunden ist. Frühere rekreative Sportaktivitäten, sowie eine Herkunft in Verbindung mit dem Standort, stellten sich sogar als wichtige Faktoren für ausgeprägtere Anziehungsmotive für den Besuch dieser Sportveranstaltung heraus. Die Bildungsebene stellte sich nicht als bedeutender Faktor für den Unterschied zwischen den Motivarten bei der Zielpopulation dar. Die Ergebnisse gewähren Initialdaten über Profilierungsmöglichkeiten für potentielle Touristen, die gerade diese Sportveranstaltung zu einem Besuch dieses Standorts motivieren könnte.
\end{abstract}

Schlüsselwörter: DUBROVNIK / ABSTOßFAKTOREN / ANZIEHUNGSFAKTOREN / SPORTTOURISMUS

Received: 18.05.2016.

Accepted: 02.11.2016.

(c) 2016 The Author. Published by Physical Culture (www.fizickakultura.com). This article is an open access article distributed under the terms and conditions of the Creative Commons Attribution license (http://creativecommons. org/licenses/by/3.0/rs/). 


\title{
„ДИВЉА ЛИГА" У ВАТЕРПОЛУ: ИСПИТИВАЊЕ МОТИВИСАНОСТИ ЗА ПОСЕКИВАҢЕ РЕКРЕАТИВНИХ СПОРТСКИХ ДОГАЋАЈА
}

\author{
Јошко Синдик \\ Институт за антрополошка истраживања Загреб, Хрватска
}

\begin{abstract}
Сажетак
Сврха овог истраживања је да се идентификују мотивациони фактори у вези са одређеним рекреативним спортским догађајем “Дивља лига” у ватерполу који се одржава у Дубровнику и има веома дугу традицију. Први циљ ове студије је да се утврди однос између мотивационих фактора у везаи са овим догађајем, као и однос са социодемографским варијаблама. Други циљ је да се утврде разлике у мотивационим факторима, према неколико независних варијабли, углавном повезаних са претходним искуствима у вези са спортским и туристичким дестинацијама. Спроведена је трансверезална студија. Узорак од 125 учесника је испитан помоћу Упитника о спортском догађају. Сви учесници су хрватски држављани, поред оних који су рођени и тренутно живе у Дубровнику. Добијени су главни спортско-туристички мотиви потенцијалних туриста заинтересованих за овај спортски догађај. Уопштено, превладао је значај предности спортске и туристичке дестинације, у поређењу са ограничењима, која су се јавила као значајан фактор једино код учесника који још увек нису посетили Дубровник. Код учесника, фактори привлачења, тј. виши спортски и туристички мотиви незнатно доминирају у односу на факторе одбијања, али су статистички значајни само код жена које су изразиле софистицираније туристичке факторе привлачења, попут стицања знања о дестинацији. Корелације указују на то да је претходна заинтересованост за спорт, нарочито за ватерполо и Дивљу лигу, умерено позитивно повезана са мотивима одбијања. Штавише, претходно рекреативно бављење спортом, као и порекло повезано са дестинацијом, показали су се као важни фактори за израженије мотиве привлачења за посећивање овог спортског догађаја. Ниво образовања се није показао као значајан фактор у разликовању главних врста мотива код циљне популације. Резултати пружају иницијалне податке о могућности профилисања потенцијалних туриста који би могли бити мотивисани управо овим спортским догађајем да посете ову дестинацију.
\end{abstract}

КљУчне речи: ДУБРОВНИК / ФАКТОРИ ОДБИЈАҢА / ФАКТОРИ ПРИВЛАЧЕЊА / СПОРТСКИ ТУРИЗАМ

\section{УВОД}

Ово истраживање има основни циљ испитивање мотивисаности за спортски туризам у контексту рекреативног ватерполо такмичења „Дивља лига” у Дубровнику. Увиди из ове студије могу да обезбеде смернице о могућности унапређења услова за спортски и/или културни туризам у смислу атрактивног локалног спортско-рекреативног догађаја.

\section{Спортски туризам}

Спортски туризам подразумева путовање из примарног места боравка због учествовања у спортским активностима (рекреативним или такмичарским), путовање услед учешћа у спортским такмичењима на врхунском нивоу, као и посете спортским атракцијама, као што су аква паркови или „куће славних” (Gibson, Attle, \& Yiannakis, 1997; Gibson, 2004). Основни ресурси одређене туристичке дестинације су природни и културни ресурси, туристички објекти, телекомуникациона инфраструктура, смештај и угоститељски објекти. Комбинација локалних туристичких ресурса и услуга које се нуде одређује врсту туризма која припада одређеном месту: на пример, приморски (морски), планински туризам, спортски и верски туризам, гастрономски, конгресни или пословни туризам (HM Government, 2014). 


\section{Мотиви у спортском туризму: фактори одбијања и фактори привлачења}

Туризам и спорт су кључни елементи савремене културе који значајно утичу на друштво у целини (Ottevanger, 2007; Whyte, Hood, \& White, 2012). У оквиру спортског туризма, постоји суштинска разлика између активног и пасивног учествовања спортске публике. Протеклих (неколико десетина) година дошло је до значајног пораста у спортском туризму у вези са спортским догађајима, а за многе туристе, који посећују или учествују у спортским догађајима, то је постао главни разлог за путовања (Delpy, 1997). Већина мотива спортског туризма у литератури тежи да категорише разлоге мотивисаности за туристичка путовања као „бежање од” (нпр. буке, свакодневне рутине на послу, рутине уопште, итд.) и/или „трчање ка” (нпр. местима где се са сигурношћу може опустити или забавити) одређеној дестинацији (Pizam, \& Mansfeld, 2000; Mohamed, \& Othman, 2012).

Фактори „одбијања” (push factors) углавном представљају социопсихолошку мотивацију, засновану на потреби да се „побегне” од тренутног свакодневног окружења људи. Жеља да се побегне на одређену туристичку дестинацију (због њене атрактивности, или из неког другог разлога) може cе назвати „факторима привлачења” (pull factors) (Ottevanger, 2007). Дан (1977, од Kim, \& Chalip, 2004) пружа основни модел са седам различитих категорија туристичке мотивације. Оне су: туристичка путовања која представљају реакцију на оно што некоме тренутно недостаје (фактори одбијања); привлачност одређене дестинације (фактори привлачења); жеља да се оствари сопствена фантазија; мотивација са јасним циљем, попут посете пријатељима или рођацима или путовање ради учења; различите врсте мотивације; претходно доживљено мотивационо искуство; мотивација која је самодефинисана (у смислу да је боље дефинисати туристе у оквиру одређених ситуација, а не само посматрањем њиховог понашања). Кромптон продубљује Данову теорију фактора одбијања и привлачења и сматра да постоји девет мотива за туристичка путовања, од којих је седам социопсихолошких или мотива одбијања, док су преостала два културолошки или фактори привлачења (Crompton, 1979, од Kim, \& Chalip, 2004). Мотиви одбијања су бежање, самоиспитивање, опуштање, престиж, регресија и друштвена интеракција. Мотиви привлачења су иновације и образовање. Могу се идентификовати две главне врсте мотива одбијања и привлачења: лични и међуљудски (Mannel \& Iso-Ahola, 1987, od Pizam, \& Mansfeld, 2000). Они истичу да је сврха обе врсте мотива чињеница да људи желе да оставе иза себе личне и међуљудске проблеме, као и да стекну личне и интерперсоналне награде и признања. Личне награде су самоопредељење, осећај компетентности, изазов, учење, истраживање и опуштање. Интерперсоналне награде су резултати друштвене интеракције (Pizam, \& Mansfeld, 2000).

\section{Друге категоризације мотивисаности за спортски туризам}

Холов модел (Hall,1992) прави разлику између две врсте активног учешћа у спортском туризму: активни учесници сматрају њихово учешће средством самоизражавања, док такмичари имају јаке такмичарске мотиве у овом активном учествовању. Са друге стране, пасивни конзументи спорта не учествују у спортским активностима, али прате ове велике спортске догађаје путем истакнутих спортских сајтова на интернету или праћењем спортских вести. Гамонов \& Робинсонов модел (Gammon, \& Robinson, 1997) разликује два облика спортског туризма: израз „спортски туризам” се користи ако је спорт главни разлог за путовање, док се израз „туристички спорт” користи када је учешће у спортским активностима секундарна активност међу многим другим активностима. Стандевен \& Де Кноп (Standeven, \& De Knop, 1999) праве разлику између различитих циљева спортског туризма. Један принцип се заснива на циљу одмора (људи путују да би се одморили, а за неке од њих то није сврха њиховог путовања), док је други принцип присуство или одсуство потребе да се буде активни или пасивни спортски туриста. Пасивни спортски туристи су они који желе да посете спортске догађаје или спортске музеје. Активни спортски туристи се могу ठавити спортским активностима уз одмор, где је спорт главна сврха путовања, или могу отићи на одмор са спортским активностима, где је спорт придружена активност. Поред аутора који разликују пасивну публику и активно учешће, постоји и неколико других теорија. Вид \& Бул (Weed, \& Bull, 2004) разликују пет категорија спортског туризма: спортски тренинг, спортски догађаји, врхунски спортски догађаји, спортски туризам са активним учешћем и туризам са повременим учешћем у спортским активностима. Ривес (Reeves 2000 , od Hinch, \& Higham, 2004) је идентификовао 
шест различитих врста посетилаца у спортском туризму који се деле на: случајне, спорадичне, повремене, редовне, посвећене и компулсивне.

\section{Досадашња сазнања}

Међу бројним студијама у овој области, Греин и Чалип (Green, \& Chalip, 1998) су испитивали фудбалерке у Сједињеним Америчким Државама, које су учествовале на годишњем турниру на Флориди. Њихово истраживање је открило да играње фудбала недалеко од куће или места (Флорида) није мотив који привлачи играче, већ чињеница да могу да буду заједно са колегама који се баве истим спортом, а потичу из удаљених места у САД. Ким и Чалип (Kim, \& Chalip, 2004) су испитивали 600 Американаца који су ишли на Светско првенство у фудбалу у Јужној Кореји и Јапану 2002. године и добили резултате да је главни разлог њихове посете Јужној Кореји и/или Јапану њихова заинтересованост за Мундијал. Финансијска ограничења негативно утичу на људе који посећују сличне догађаје. Занимљиво је да људи имају способност да сами створе особину неког спортског центра. Пример таквог новог „спортског центра" који се недавно појавио је скуп обожавалаца фудбала који гледају утакмице на јавним местима на привремено постављеним ТВ екранима, нпр. током Светског првенства у Немачкој 2006 (Hinch, \& Higham, 2004). Окупљени људи стварају место које привлачи људе који нису нарочито заинтересовани за спорт, али просто воле „да буду у спортској атмосфери”. Постоје три особине од значаја за спортски туризам: приврженост месту, идентитет места и зависност од места (Hinch, \& Higham, 2004). У студији о мотивисаности за посету Вимблдонском турниру, доказано је да су мотиви за забаве главни разлог због чега људи желе да посете овај велики спортски догађај, док је други мотив привлачност дестинације домаћина (Ottevanger, 2007). Изненађујуће је да су свечаности које прате овај догађај за гледаоце важније од самог такмичења. Посета овом великом спортском догађају (за разлику од других облика туризма) се не доживљава као „време за одмор" (Ottevanger, 2007).

\section{Дивља лига као спортски догађај}

Моћни положај који град Дубровник поседује као дестинација културног туризма значи проналажење нових облика представљања и промоције овог туристичког центра (Rudan, 2012), док се ис- товремено тежи да се сачува дубровачка култура и традиција (Vrtiprah, 2006). Локални традиционални спортски догађаји (заправо рекреативни спорт), које туристи посматрају или у којима активно учествују, могу се развити у атрактиван туристички производ (Šiljeg, Perinić Lewis, \& Sindik, 2014). „Дивља лига” (Wild League), као културна и спортска манифестација, нуди широк спектар импресивних, формалних културних производа. То је истовремено весела и слојевита традиција, као и дух локалне дубровачке атмосфере (Šiljeg et al., 2014). Дивља лига је популарно аматерско такмичење у ватерполу, које се одржава на плажама Дубровника. Иако се заснива искључиво на ентузијазму и волонтерским активностима свих учесника и организатора, правила и прописи су прецизно дефинисани и стриктно се поштују (Šiljeg et al., 2014). Овај турнир има изразито локални карактер. Први предуслов за играње на овом турниру је да сте мештанин (Дивља лига 2015). Чињеница да се турнир Дивља лига одржава у периоду од краја јула до средине августа значи да би овај локални рекреативни спортски догађај могао бити много боље укључен у туристичку понуду, представљајући културни и економски потенцијал града и државе (Šiljeg et al., 2014).

Стога, као саставни део производа спортског (рекреативног) и културног туризма, Дивља лига би требало да буде на бољи начин истакнута у туристичкој понуди Дубровника. У овој студији су истраживани изазови афирмисања Дивље лиге као посебног бренда Дубровника увидом у разлике и повезаности између мотива спортског туризма, различитих социодемографских варијабли, као и варијабли везаних за ово питање (заинтересованост за спорт, дубровачко наслеђе, итд).

Дакле, општи циљ овог истраживања је био да се одреде фактори повезани са спортским туризмом у контексту рекреативног ватерполо такмичења Дивља лига у Дубровнику, код хрватских држављана, који заправо могу бити потенцијални туристи. Први циљ ове студије је био да се утврди корелација између веома различитих мотива спортског туризма, а затим и корелација између ових мотива и година старости учесника, нивоа њиховог образовања и трајања праћења овог спортског догађаја. Други циљ је био да се утврде разлике у мотивима спортског туризма у односу на пол и брачни статус учесника. 


\section{МЕТОД}

\section{Узорак испитаника}

Испитан је циљани узорак од 125 учесника. Хрватско држављанство је био критеријум за широку укљученост у истраживање, поред оних учесника који су рођени и тренутно живе у Дубровнику. По старосној групи, дистрибуција учесника је била како следи: 21-30 (17), 31-40 (35), 41-50 (42), 51-60 (24), године старости >60 (5). Према полу, учествовало је 44 мушкарца и 81 жена. Према учесталости претходних боравака у Дубровнику и његовој околини (Н), дистрибуција учесника је била како следи: никад (5), једном или два пута (26), 3-5 (46), више од 6 пута (48). Према разлогу зашто су најчешће посећивали Дубровник и његову околину (Н), дистрибуција учесника је била како следи: никада нисам био/ ла у Дубровнику (5), пословно (22), приватно-туристички (77) и приватно - други разлози (21). Према нивоу образовања $(\mathrm{H})$, учесници су дистрибуирани како следи: средња стручна спрема (6), виша стручна спрема (БА) (16), висока стручна спрема (дипл.) (66), магистар наука (МСц) (19) и доктор наука (ПхД) (18). Према њиховом ангажовању у спорту $(\mathrm{H})$, учесници су распоређени како следи: незаинтересовани за спорт (4), немам времена за бављење спортом (10), бавио/ла сам се спортом рекреативно у прошлости (26), бавио/ла сам се спортом активно у прошлости (23), бавим се рекреативно спортом сада (58), бавим се активно спортом сада (4). Према дубровачком наслеђу, 110 учесника нема дубровачко наслеђе, 6 учесника има ближе рођаке у Дубровнику, док је 9 учесника рођено у Дубровнику или његовој околини. Према заинтересованости за спорт (Ликертова скала опсега од 1- апсолутно незаинтересован до 5- апсолутно заинтересован), средња вредност је 4 (заинтересован за спорт). Према заинтересованости за ватерполо (Ликертова скала опсега од 1- апсолутно незаинтересован до 5- апсолутно заинтересован), средња вредност је 3 (равнодушан/ на према ватерполу). На питање „Да ли сте чули за Дивљу лигу?” (са Ликертовом скалом опсега од 1- никада нисам чуо/ла до 5- веома сам упознат/а са овим догађајем), средња вредност је 3 .

\section{Мерења}

У студији је коришћен прилагођени упитник о спортском туризму (Упитник о спортском догађају), који је користио Оттевангер (2007, на основу Pizam,
\& Mansfeld 2000; Robinson, \& Gammon, 2004). Први сет ставки се односи на већину демографских варијабли и претходно спортско искуство, док се ставке $\delta$ p. 1- 8 односе на факторе одбијања (категорије: бежање од свакодневног живота, опуштање, самоиспитивање, забава и дружење). Ставке бр. 9-16 се односе на факторе привлачења (категорије: вести, самостално усавршавање и дестинација). На крају, ставке бр. 17-20 се односе на ограничења (категорија: ризици и опасности). Процене за сваку ставку су изражене на Ликертовој скали од пет ступњева, крећући се у опсегу од уопште се не слажем (1) до у потпуности се слажем (5). У овом истраживању, димензије упитника су показале задовољавајући тип поузданости унутрашње конзистентности. Кронбахов алфа коефицијент за факторе одбијања је износио 0.885 , за факторе привлачења 0.736 и за ограничења 0.638. Упитник је подељен учесницима, преведен на хрватски језик. Подаци су прикупљани у периоду од октобра до новембра 2015. године, путем онлајн анкете (Google Surveys tool - Гуглова алатка за истраживања), док су учесници упознати са научном сврхом истраживања и загарантована им је анонимност.

\section{Обрада података}

Корелације су израчунаване помоћу Спирмановог коефицијента ранг корелације, док су разлике између два независна узорка испитаника испитиване помоћу т-тестова за независне узорке или помоћу Man Vitni U-теста. Kruskal-Valis тестови су коришћени за испитивање разлика између више од два независна узорка испитаника. На све статистичке значајности осврнули смо се на нивоу значајности од п $<0.05$ и п $<0.01$. Статистичка анализа је обављена коришћењем статистичког пакета SPSS 23.0.

\section{РЕЗУЛТАТИ}

Табела 1 показује разлике у мотивима спортског туризма према полу учесника и дубровачком наслеђу. Нису пронађене никакве статистички значајне разлике према полу у мотивима спортског туризма. У смислу дубровачког наслеђа (ближи рођаци или рођени у Дубровнику насупрот оних без дубровачког наслеђа), једина значајна разлика је откривена у мотивима одбијања. Учесници са дубровачким наслеђем су показали израженије мотиве одбијања у односу на оне који то наслеђе немају. 
Табела 1. Разлике у мотивима спортског туризма, према полу и дубровачком наслеђу

\begin{tabular}{|c|c|c|c|c|}
\hline Мотиви & Пол & M & SD & t-тест $(\mathrm{df}=99)$ \\
\hline \multirow[t]{2}{*}{ Одбијање } & мушки & 25.53 & 7.75 & \multirow{2}{*}{1.88} \\
\hline & женски & 22.22 & 8.46 & \\
\hline \multirow[t]{2}{*}{ Привлачење } & мушки & 22.00 & 4.64 & \multirow{2}{*}{0.04} \\
\hline & женски & 21.96 & 5.30 & \\
\hline \multirow[t]{2}{*}{ Ограничења } & мушки & 7.94 & 2.75 & \multirow{2}{*}{-1.34} \\
\hline & женски & 8.78 & 3.04 & \\
\hline Мотиви & Наслеђе & & SD & $\begin{array}{c}\text { Mann Whitney } \\
\text { U-тест }\end{array}$ \\
\hline \multirow[t]{2}{*}{ Одбијање } & не & 22.21 & 8.11 & \multirow{2}{*}{$-4.81^{\star *}$} \\
\hline & да & 31.08 & 5.65 & \\
\hline \multirow[t]{2}{*}{ Привлачење } & не & 21.88 & 5.06 & \multirow{2}{*}{-0.51} \\
\hline & да & 22.67 & 5.37 & \\
\hline \multirow[t]{2}{*}{ Ограничења } & не & 8.58 & 2.87 & \multirow{2}{*}{0.64} \\
\hline & да & 8.00 & 3.67 & \\
\hline
\end{tabular}

** разлике значајности $\mathrm{p}<0.01$; ${ }^{*}$ разлике значајности $\mathrm{p}<0.05$

Разлике у мотивима спортског туризма, према личном анагажовању у спорту, нису статистички значајне (Табела 2).

Табела 2. Разлике у мотивима спортског туризма, према личном анагажовању у спорту

\begin{tabular}{|c|c|c|c|c|c|}
\hline Мотиви & Ангажовање у спорт у & Med & $\mathbf{M}$ & SD & Kruskal Wallis (p) \\
\hline \multirow{3}{*}{ Одбијање } & $\begin{array}{l}\text { не (незаинтересовани / нема } \\
\text { времена) }\end{array}$ & 23 & 20.09 & 8.07 & \multirow{3}{*}{0.38} \\
\hline & $\begin{array}{l}\text { да, активно или рекреативно } \\
\text { раније }\end{array}$ & 22 & 23.10 & 8.78 & \\
\hline & да, активно или рекреативно сада & 22 & 24.10 & 8.04 & \\
\hline \multirow{3}{*}{ Привлачење } & $\begin{array}{l}\text { не (незаинтересовани / нема } \\
\text { времена) }\end{array}$ & 22 & 20.91 & 3.81 & \multirow{3}{*}{0.27} \\
\hline & $\begin{array}{l}\text { да, активно или рекреативно } \\
\text { раније }\end{array}$ & 22 & 21.63 & 4.59 & \\
\hline & да, активно или рекреативно сада & 23 & 22.48 & 5.67 & \\
\hline \multirow{3}{*}{ Ограничења } & $\begin{array}{l}\text { не (незаинтересовани / нема } \\
\text { времена) }\end{array}$ & 11 & 8.45 & 3.91 & \multirow{3}{*}{0.64} \\
\hline & $\begin{array}{l}\text { да, активно или рекреативно } \\
\text { раније }\end{array}$ & 9 & 8.23 & 2.72 & \\
\hline & да, активно или рекреативно сада & 8 & 8.76 & 2.96 & \\
\hline
\end{tabular}

** разлике значајности $\mathrm{p}<0.01$; ${ }^{*}$ разлике значајности $\mathrm{p}<0.05$

Разлике у мотивима спортског туризма према најчешћим разлозима за боравак у Дубровнику су статистички значајне и за мотиве одбијања и за ограничења (Табела 3). Учесници који у Дубровник долазе због приватних - других посета имају највише мотиве одбијања, док су најниже средње вредности откривене код приватних - туристичких посета. Са друге стране, учесници који никада нису били у Дубровнику примећују највиша ограничења, док су ограничења најмања за оне који долазе у Дубровник због приватних - других разлога. 
Табела 3. Разлике у мотивима спортског туризма, према најчешћим разлозима боравка у Дубровнику

\begin{tabular}{|c|c|c|c|c|c|}
\hline Мотиви & $\begin{array}{c}\text { Најчешћи } \\
\text { разлози боравка у } \\
\text { Дубровнику }\end{array}$ & $\mathbf{M}$ & $\mathbf{M}$ & SD & Kruskal Wallis (p) \\
\hline \multirow{4}{*}{ Одбијање } & никад у Дубровнику & 23 & 23.50 & 5.51 & \multirow{4}{*}{$0.02^{\star}$} \\
\hline & посао & 22 & 22.28 & 9.26 & \\
\hline & $\begin{array}{l}\text { приватно- } \\
\text { туристички }\end{array}$ & 22 & 21.97 & 8.06 & \\
\hline & приватно - друго & 31 & 29.00 & 6.97 & \\
\hline \multirow{4}{*}{ Привлачење } & никад у Дубровнику & 22 & 20.75 & 4.03 & \multirow{4}{*}{0.93} \\
\hline & посао & 22 & 22.33 & 6.10 & \\
\hline & $\begin{array}{l}\text { приватно- } \\
\text { туристички }\end{array}$ & 23 & 21.79 & 4.70 & \\
\hline & приватно - друго & 23 & 22.53 & 5.77 & \\
\hline \multirow{4}{*}{ Ограничења } & никад у Дубровнику & 11 & 11.75 & 0.96 & \multirow{4}{*}{$0.04^{*}$} \\
\hline & посао & 9 & 9.50 & 2.71 & \\
\hline & $\begin{array}{l}\text { приватно- } \\
\text { туристички }\end{array}$ & 8 & 8.13 & 2.85 & \\
\hline & приватно - друго & 8 & 8.12 & 3.39 & \\
\hline
\end{tabular}

** разлике значајности $\mathrm{p}<0.01$; * разлике значајности $\mathrm{p}<0.05$

У Табели 4 су приказане корелације између мотива спортског туризма, нивоа образовања, старосне групе и других варијабли, за све учеснике заједно, као и за жене и за мушкарце одвојено. Што се тиче мотива одбијања, корелације са другим варијаблама (осим интеркорелација између спортских мотива) имају веома сличне величине, правце и нивое значаја код мушкараца, жена, као и свих учесника заједно. Позитивне и умерено високе корелације су откривене код варијабли: заинтересованост за спорт уопште, заинтересованост за ватерполо и претходна сазнања о Дивљој лиги. Што се тиче мотива привлачења, корелације са другим варијаблама су генерално мањих величина (иако су позитивно усмерене) у поређењу са мотивима одбијања.
Све ове корелације са мотивима привлачења нису биле значајне код мушкараца, док су код свих учесника откривене значајне корелације код заинтересованости за ватерполо и претходних сазнања о Дивљој лиги. Једино су код жена пронађене значајне корелације са мотивима привлачења код заинтересованости за ватерполо. Коначно, једина мала и негативна корелација са ограничењима је откривена код претходног боравка у Дубровнику (и његовом окружењу), код свих ученсика и код жена (не и код мушкараца). Иако су мотиви одбијања и мотиви привлачења умерено високи и показују позитивну интеркорелацију код сва три узорка учесника, мотиви привлачења умерено и позитивно корелирају са ограничењима једино код мушкараца. 
Табела 4. Корелације између мотива спортског туризма, нивоа образовања, старосне групе и других варијабли

\begin{tabular}{|c|c|c|c|}
\hline Сви испитаници & одбијање & привлачење & ограничења \\
\hline Ниво образовања & -.020 & -.102 & -.048 \\
\hline Старосна група & .125 & .027 & -.028 \\
\hline Колико пута били у Дубровнику и околини? & .130 & -.058 & $-.293^{* *}$ \\
\hline Општа заинтересованост за спорт? & $.431^{* *}$ & .175 & .156 \\
\hline Заинтересованост за ватерполо? & $.601^{* *}$ & $.318^{* *}$ & .064 \\
\hline Да ли сте раније чули за Дивљу лигу? & $.454^{* *}$ & $.201^{*}$ & -.088 \\
\hline Мотиви одбијања & 1 & $.575^{* *}$ & .166 \\
\hline Мотиви привлачења & & 1 & .186 \\
\hline Ограничења & & & 1 \\
\hline Мушкарци & одбијање & привлачење & ограничења \\
\hline Ниво образовања & .031 & -.324 & -.096 \\
\hline Старосна група & .145 & -.019 & -.125 \\
\hline Колико пута били у Дубровнику и околини? & -.052 & -.229 & -.265 \\
\hline Општа заинтересованост за спорт? & $.407^{*}$ & .337 & .324 \\
\hline Заинтересованост за ватерполо? & $.554^{* *}$ & .190 & .037 \\
\hline Да ли сте раније чули за Дивљу лигу? & $.516^{* *}$ & .203 & .019 \\
\hline Мотиви одбијања & 1 & $.582^{* *}$ & .248 \\
\hline Мотиви привлачења & & 1 & $.602^{* *}$ \\
\hline Ограничења & & & 1 \\
\hline Жене & одбијање & привлачење & ограничења \\
\hline Ниво образовања & -.059 & -.012 & -.016 \\
\hline Старосна група & .117 & .047 & .017 \\
\hline Колико пута били у Дубровнику и околини? & .135 & -.004 & $-.271^{*}$ \\
\hline Општа заинтересованост за спорт? & $.398^{* *}$ & .139 & .183 \\
\hline Заинтересованост за ватерполо? & $.594^{* *}$ & $.381^{* *}$ & .130 \\
\hline Да ли сте раније чули за Дивљу лигу? & $.392^{* *}$ & .210 & -.079 \\
\hline Мотиви одбијања & 1 & $.585^{* *}$ & .176 \\
\hline Мотиви привлачења & & 1 & .039 \\
\hline Ограничења & & & 1 \\
\hline
\end{tabular}

** разлике значајности $\mathrm{p}<0.01 ;{ }^{*}$ разлике значајности $\mathrm{p}<0.05$

\section{ДИСКУСИЈА}

У почетку, када се размотре просечне вредности резултата за мотиве одбијања и привлачења и уочена ограничења у спортском туризму, повезана са Дивљом лигом (укупно за све учеснике, за различите независне варијабле), може се уочити да су резултати за мотиве одбијања и привлачења око или незнатно изнад теоретског просека. Са друге стране, уочена ограничења су око или незнатно испод теоретског просека. Ови резултати могу указивати на два објашњења. Прво да је Дивља лига веома специфична спортска (и/или културна) манифестација која је привлачна само специфичним профилима туриста. Друго, углед Дубровника као туристичке дестинације има потенцијал да превазиђе многа ограничења, које туристи опажају, нарочито они који су раније посетили Дубровник.

Разлике у мотивима спортског туризма нису очигледне према полу нити према личном ангажовању учесника у спорту. Дубровачко наслеђе се појављује као фактор који је повезан са јачим мотивима одбијања. Слично томе, јачи мотиви 
одбијања су у већој мери повезани са путовањем у Дубровник из личних разлога (нетуристичких). Мотиви одбијања су снажније повезани са заинтересованошћу за спорт уопште, као и за ватерполо и са (више) претходних сазнања о Дивљој лиги. На основу ових резултата, изгледа да су мотиви одбијања ове специфичне врсте спортског (и културног) туризма наглашенији код учесника који имају рођаке (или пријатеље) у Дубровнику, незвисно од пола и личног ангажовања у спорту. Они вероватно имају више позитивног искуства у вези са боравком у Дубровнику, не (само) оних повезаних са спортским или културним догађајима. Може се сматрати да фактори одбијања позитивне мотивације за спортски туризам могу да превазиђу ограничења код наших учесника, који вероватно већу пажњу поклањају предностима ове спортске туристичке дестинације, него ограничењима (Sindik, 2014). Ова специфична усмереност на предности може потенцијално да укаже на привлачност ове туристичке дестинације туристима (Ottevanger, 2007). Сходно томе, разумљиво је то што су учесници који никада нису били у Дубровнику опажали највише ограничења, док су негативне корелације откривене између претходне посете Дубровнику (и његовој околини) код свих учесника, и код жена. Позитивна интеркорелација између мотива одбијања и привлачења код свих учесника се може једноставно објаснити у смислу привлачности неке туристичке дестинације, која истовремено може представљати место за опуштање (бежање од) и место које је нарочито атрактивна дестинација (одлазак у то место) (Kim, \& Chalip, 2004). Мотиви привлачења су позитивно и значајно повезани са интересовањем за ватерполо, али само код жена. Као провизорни „виши” психолошки мотиви (привлачност дестинације је важнија од бежања од свакодневног живота), изгледа да су мотиви привлачења у већој мери повезани са овим специфичним интересовањем код жена учесника у истраживању. Ово откриће би могло бити изненађујуће, али није када се узме у обзир чињеница да је спортски туризам (нарочито овај спортско-рекреативни) више културни него типично спортски догађај. Наиме, што се тиче активног физичког вежбања, на пример код популације студената, мушкарци су више мотивисани интринзичким факторима (жеља за моћи, надметањем и изазовом), док су жене чешће вођене екстринзичким мотивима (контрола телесне тежине и изглед) (Egli, Bland, Melton, \& Czech, 2011). Активно учешће у спорту може бити привлачно из неколико врста мотива: забава, уживање, унапређење вештина, и учење, провођење времена са пријатељима, успех, победа и здравље (Gaston-Gayles, 2005; Mouratadis, Vansteenkiste, Lens, \& Sideridis, 2008; Waldron, \& Dieser, 2010). Вероватан разлог због чега мотиви привлачења позитивно корелирају са ограничењима само код мушкараца може бити израженија потреба за одмором код мушкараца него код жена. Потреба да се опусте кроз спорт и физичке активности може бити јаче израженија код мушкараца (Egli et al., 2011). У претходном истраживању где је коришћен сличан мерни инструмент у Хрватској, резултати су открили да жене посматрачи одређеног спортског догађаја (првенство у виндсурфу) имају израженије мотиве привлачења (иновације и образовање) (Sindik, 2014). Слично томе, могуће објашњење би могло водити у том правцу да жене нису само „обожаватељке” играча рекреативног ватерпола. Оне можда имају софистициранија интересовања него мушкарци (спорт, култура, итд). Све у свему, чини се да у вези са догађајем Дивља лига, атрактивност дестинације је бар у сличној мери значајна колико и спортско рекреативни догађај. Супротно томе, у случају тениског турнира Вимблдон (Ottevanger, 2007) или Светског првенства у фудбалу у Јужној Кореји и Јапану 2002. године (Kim, and Chalip, 2004), спортски догађаји су сами по себи били доминантан разлог за посету одређених дестинација. Међутим, Дивља лига је вероватно више културна туристичка него спортско рекреативна манифестација. Ричардс (Richards, 2002) указује на то да пораст у културном туризму произилази из растуће понуде културних атракција и све већег броја туриста. Раст тржишта културног туризма је праћен сегментацијом тржишта, али и растућом конкуренцијом (Outspan Group Inc., 2009). У оквиру овог такмичења, нове могућности тржишта се могу сагледати кроз развој креативног туризма (Richards, 2002; Rudan, 2012).

Главни недостатак овог истраживања је релативно мали и недовољно репрезентативни (циљани) узорак испитаника. Ово је уједно разлог ограничене могућности веће генерализације добијених резултата. Упркос релативно малом броју испитаника, примена оригиналног мерног инструмента је показала задовољавајућу поузданост 
и препознатљивост. Међутим, иако је могућност генерализације резултата у овом истраживању мала, резултати могу пружити одређени увид у мотивисаност потенцијалних туриста мотивисаних Дивљом лигом као спортско-рекреативним и културним догађајем. Као основна предност овог истраживања се може нагласити чињеница да је ово вероватно једина студија која је квантитативно истраживала Дивљу лигу као „посебан туристички потенцијал” (Šiljeg et al., 2014). Стога, практична импликација ове студије би се могла углавном односити на коришћење ових показатеља и припадајућег мерног инструмента (међутим, и ових прелиминарних резултата такође) у процени Дивље лиге као „посебног туристичког потенцијала". Могућности у области спортског туризма, путем увећања потенцијала одређене дестинације разумевањем свих елемената који су саставни до спортског туризма (Delpy, 1997), могу се применити и у овом случају. Наиме, Дивља лига би се могла сместити у оквир различитих туристичких пакета, повезаних са остатком спортске и/или културне понуде.

\section{ЗАКЉУЧАК}

Резултати су показали да није било статистички значајних разлика према полу испитаника у мотивима спортског туризма, као ни према личном ангажовању учесника у спорту, док је једино

\section{ЛИТЕРАТУРА}

1. Vrtiprah, V. (2006). Kulturni resursi kao činitelj turističke ponude u 21. stoljeću. Ekonomska misao i praksa, 15(2), 279-296.

2. Waldron, J.J., \& Dieser, R.B. (2010). Perspectives of fitness and health in college men and women. Journal of College Student Development, 51, 65-78.

3. Weed, M., \& Bull, C. (2004). Sport Tourism: Participants, Policy and Providers. Burlington: Elsevier Publishing.

4. Whyte, B., Hood, T. \& White, B.P. (eds). (2012). Cultural and Heritage Tourism: A Handbook for Community Champions. Ottawa, Canada: Federal Provincial Territorial Ministers of Culture and Heritage. једна статистички значајна разлика откривена код дубровачког наслеђа. Испитаници са дубровачким наслеђем су показали веће мотиве одбијања, у односу на оне без дубровачког наслеђа. Највише мотиве одбијања су показали учесници који у Дубровник одлазе због приватних разлога - других посета, док испитаници који никада нису били у Дубровнику уочавају највише ограничења. Позитивне и умерено високе корелације са мотивима одбијања су пронађене код заинтересованости за спорт уопште, као и ватерполо, и претходних сазнања о Дивљој лиги. Једино код жена су пронађене значајне корелације са мотивима привлачења код заинтересованости за ватерполо. Мала и негативна корелација са ограничењима је пронађена код претходног боравка у Дубровнику (и његовој околини), код свих учесника и код жена. Мотиви одбијања и мотиви привлачења су били у позитивној интеркорелацији код сва три узорка испитаника, док мотиви привлачења позитивно корелирају са ограничењима једино код мушкараца. Најразумније објашњење добијених резултата је то да је Дивља лига веома специфична спортска и културна манифестација која привлачи само специфичне профиле туриста. Са друге стране, Дубровник је сам по себи веома атрактивна дестинација, која превазилази многа запажена ограничења. Дакле, постоје бројне могућности да се Дивља лига уврсти у оквир неколико интересантних туристичких пакета, повезаних са остатком спортске и/или културне понуде.

5. Gammon, S., \& Robinson, T. (1997). Sport and tourism: A conceptual framework. Journal of Sport Tourism, 4(3), 8-24.

6. Gaston-Gayles, J.L. (2005). The Factor Structure and Reliability of the Student Athletes' Motivation toward Sports and Academics Questionnaire (SAMSAQ). Journal of College Student Development, 46, 317-327.

7. Gibson, H. (2004). Moving beyond the „what is and who" in sport tourism to understanding „why“. Journal of Sport Tourism, 9(3), 247-265.

8. Gibson, H., Attle, S, \& Yiannakis, A. (1997). Segmenting the sport tourist market: A lifespan perspective. Journal of vacation marketing, 4(3), 52-64. 
9. Green, B., \& Chalip, L. (1998). Sport tourism as a celebration of sub-culture. Annals of Tourism Research, 25(2), 275-291.

10. Delpy, L. (1997). An overview of sport tourism: Building towards a dimensional framework. Journal of Vacation Marketing, 4(1), 23-28.

11. Divlja liga (2013). Propozicije Dostupno 18.12.2015 na http://www.divljaliga.com/?page$=$ propozicije.

12. Egli, T., Bland, H.W., Melton, B.F., \& Czech, D.R. (2011). Influence of age, sex and race on collegestudents' exercise motivation of physical activity. Journal of American College Health, 59(5), 399-406.

13. Kim, N.S., \& Chalip, L. (2004). Why to travel to the FIFA World Cup? Effects of motives, background, interest, and constraints. Tourism Management, 25, 695-707.

14. Mohamed, N., \& Othman, N. (2012). Push and Pull Factor: Determining the Visitors' Satisfactions at Urban Recreational Area. Procedia - Social and Behavioral Sciences, 49, 175-182.

15. Mouratadis, M., Vansteenkiste, M., Lens, W., \& Sideridis, G. (2008). The motivating role of positive feedback in sport and physical education: Evidence for a motivational model. Journal of Sport and Exercise Psychology, 30, 240-268.

16. Ottevanger, H.J. (2007). Sport Tourism: Factors of influence on sport event visit motivation. Master thesis. Bournemouth, UK: Bournemouth University.

17. Outspan Group Inc. (2009). The Economic Impacts of Cultural and Sport Tourism in Canada 2007. Ottawa: Department of Canadian Heritage and Industry Canada.
18. Pizam, A., \& Mansfeld, Y. (2000). Consumer behaviour in travel and tourism. New York: Haworth Hospitality Press,.

19. Richards, G. (2002). Od kulturnog do kreativnog turizma: europske perspective [From the cultural and creative tourism: European perspectives. In Croatian]. Turizam, 50(3), 228-236.

20. Robinson, T., \& Gammon, S. (2004). A question of primary and secondary motives: revisiting and applying the sport tourism framework. Journal of Sport Tourism, 9(3), 221-233.

21. Rudan, E. (2012). Razvojne perspektive kreativnoga turizma Hrvatske. Ekonomska misao i praksa, 21(2), 713-730.

22. Sindik, J. (2014). Percepcije Svjetskog prvenstva u jedrenju na dasci 2013. u Vignju sa stanovišta promatrača i natjecatelja. Naše more, 61(3-4), 81-88.

23. Standeven, J., \& De Knop, P. (1999). Sport Tourism. Leeds: Human Kinetics.

24. Hall, C. (1992). Hallmark tourist events: Impacts, management and planning. London, GB: Bellhaven Press.

25. Hinch, T., \& Higham, J. (2004). Sport Tourism Development. Clevedon: Channel View Publications.

26. HM Government (2014). Review of the Balance of Competences between the United Kingdom and the European Union Culture, Tourism and Sport, London: UK Government.

27. Šiljeg, K., Perinić Lewis, A., \& Sindik, J. (2014). Lokalna sportska tradicija kao dio dubrovačkoga kulturnog identiteta. Zbornik Sveučilišta u Dubrovniku, 1(1), 193-208. 


\title{
„WILDE LIGA“ IM WASSERBALLSPORT: UNTERSUCHUNG DER MOTIVATION FÜR DEN BESUCH VON REKREATIVEN SPORTVERANSTALTUNGEN
}

\begin{abstract}
Zusammenfassung:
Der Zweck dieser Untesuchung ist die Identifizierung von Motivationsfaktoren, die mit einer bestimmten rekreativen Sportveranstaltung verbunden sind: die „Wilde Liga“ im Wasserballsport, die in Dubrovnik organisiert wird und eine sehr lange Tradition hat. Das erste Ziel dieser Studie ist es, das Verhältnis unter den, mit dieser Veranstaltung verbundenen Motivationsfaktoren und der Beziehung zu soziodemographischen Variablen festzulegen. Ein weiteres Ziel ist es, die Unterschiede zwischen den Motivationsfaktoren auf Grund einiger unabhängiger Variablen festzulegen, die hauptsächlich auf frühere Erfahrungen in Bezug auf Sport- und Tourismusbestimmungsorte hinweisen. Es wurde eine Transversalstudie durchgeführt. Ein Muster von 125 Teilnehmern wurde mit Hilfe eines Fragebogens über die Sportveranstaltung befragt. Alle Teilnehmer sind kroatische Staatsbürger, eine bestimmte Anzahl der Teilnehmer an dieser Studie wurde in Dubrovnik geboren und lebt im Moment in dieser Stadt. Gewonnen wurden auf diese Weise die wichtigsten Sport- und Tourismusmotive potentieller Touristen, die für diese Sportveranstaltung interessiert sind. Im allgemeinen Sinne hat die Bedeutung der Vorteile des Sport- und Tourismusbestimmungsorts Übergewicht im Vergleich zu Begrenzungen, die einen bedeutenderen Faktor bei Teilnehmern darstellten, die Dubrovnik nie besucht haben. Bei den Teilnehmern weisen die Anziehungsfaktoren bzw. höhere Sport- und Tourismusmotive eine geringe Dominanz im Vergleich zu Abstoßfaktoren auf, sind aber im statistischen Sinne nur bei Frauen bedeutend, die sophistiziertere Anziehungsfaktoren anführten wie z.B. Wissenserwerb über den Standort. Korrelationen weisen darauf hin, dass ein früheres Interesse für Sport, in besonderem Maße für Wasserball und die Wilde Liga, gemäßigt positiv mit den Abstoßmotiven verbunden ist. Frühere rekreative Sportaktivitäten, sowie eine Herkunft in Verbindung mit dem Standort, stellten sich sogar als wichtige Faktoren für ausgeprägtere Anziehungsmotive für den Besuch dieser Sportveranstaltung heraus. Die Bildungsebene stellte sich nicht als bedeutender Faktor für den Unterschied zwischen den Motivarten bei der Zielpopulation dar. Die Ergebnisse gewähren Initialdaten über Profilierungsmöglichkeiten für potentielle Touristen, die gerade diese Sportveranstaltung zu einem Besuch dieses Standorts motivieren könnte.
\end{abstract}

Schlüsselwörter: DUBROVNIK / ABSTOßFAKTOREN / ANZIEHUNGSFAKTOREN / SPORTTOURISMUS

Примљен: 18.05.2016.

Прихваћен: 02.11.2016.

(c) 2016 Autor. Objavio Fizička kultura (www.fizickakultura.com). Ovo je članak otvorenog pristupa i distribuira se u skladu sa Creative Commons licencom (http://creativecommons.org/licenses/by/3.0/rs/). 